\title{
各種建築材料および吸着材の水蒸気およびホルムアルデヒド吸着等温線の測定 MEASUREMENTS OF ADSORPTION ISOTHERM OF VARIOUS BUILDING AND ADSORPTION MATERIALS
}

\author{
安宅勇二*, 加藤 信 介**, 徐 長 厚***, 朱 清 宇****, 長谷川 あゆみ***** \\ Yuji ATAKA, Shinsuke KATO, Qingyu ZHU, \\ Jang-Hoo SEO and Ayumi HASEGAWA
}

\begin{abstract}
It is very important to evaluate the adsorption and desorption property of the building materials for the indoor air pollution problem. Recently the adsorption materials and the adsorptive building materials that reduce the indoor air pollutant concentration are developed and become to be used in Japan. The test method concerning the continuous efficiency is not so examined though the test method concerning the concentration reducing performance of the adsorptive building materials is examined. It is thought that the measurement of the adsorption isotherm is effective to evaluate the continuous efficiency because there are a lot of the adsorption materials using the physical adsorption and the chemical adsorption for the adsorptive building materials. However, there are not a lot of examples of measuring the adsorption isotherms of the building material and the adsorption materials.

In this paper, two methods of the adsorption isothermal measurement are examined. The first measuring method is an examination with the adsorption amount weighing device with a magnetic suspension balance (MSB), and another is an adsorption breakthrogh capacity method. The adsorption isotherms of various building materials and the adsorption materials are measured by these two measuring methods. First of all, the water vapor adsorption isotherm of each material was measured by MSB, and the water vapor adsorption characteristic was verified. Afterwards, formaldehyde ( $\mathrm{HCHO}$ ) adsorption isotherm was measured by MSB and the adsorption breakthrogh capacity method.

The measurement of the water vapor adsorption isotherm with MSB was a very easy and a useful measuring method. Moreover, the adsorption breakthrogh capacity method was able to measure in a short time and was able to measure the HCHO adsorption isotherm easily.
\end{abstract}

Keywords : Adsorption isotherm, Building materials, Adorptive building material,Adsobent, Water vapor,Formaldehyde 吸着等温線、建築材料、パッシブ吸着建材、吸着材、水蒸気、ホルムアルデヒド

1. 序

本研究は、各種建築材料および吸着材の水蒸気およびホルムアル デヒド（HCHO）の吸着等温線の測定法を検討し、その実用的な有 用性を検証するものである。

室内空気污染問題を解明する上で、空気中の揮発性化学物質の建 築材料などに対する吸着・脱着性能が、室内化学物質濃度に少なから ず影響を与えることから、この性状を把握することは重要である 1-4)。また、最近は室内空気污染濃度を低減する吸着材や吸着建材(パ ッシブ吸着建材）が開発され、利用されるようになってきている⿱亠乂 5-8)。パッシブ吸着建材の濃度低減性能に関する試験法は検討されて いる× ${ }^{9-12)}$ 。しかしながら、濃度低減性能の持続性能に関する試験法 は必ずしも確立されていない。本来なら、パッシブ吸着建材の濃度 低減性能の持続性能は、性能低下が見られるまで試験を継続するこ とが理想である。しかし、濃度低減性能が数年にわたり持続する場 合などは、試験を継続することは労力、コストなどを考えた場合、 非常に困難である。そこで、簡易に持続性能を予測できる方法とし て、実際の室内濃度付近（例えば厚生労働省指針值程度）での飽和 吸着量を求めることで、濃度低減性能の持続性能が予測できると考 えられる。また、持続性能を評価する上で、パッシブ吸着建材は物 理吸着や化学吸着（化学反応）を利用したものが多いことから、室
内化学物質空気污染が問題となる比較的低濃度領域の吸着等温線の 測定が有効であると考えられる。しかしながら、建築材料・吸着材な どの吸着等温線の測定例は必ずしも多いとはいえない文14-17)。

本報では吸着等温線測定法として、(1) 磁気浮遊天秤を用いた吸着 量測定装置 (MSB) による試験、(2) 吸着破過試験について検討し、 各種建築材料·吸着材の吸着等温線の測定を行い、その基礎的な検討 を行なう。その検討はまず、MSBにより水蒸気吸着等温線が測定可 能であるか検討した後、各試料の水蒸気吸着特性を確認する。これ は、 $\mathrm{HCHO}$ 吸着等温線測定時に水蒸気吸着の影響を把握するための 基礎データともなる。また、水蒸気吸着等温線の測定法に関しては、 JIS A 1475-建築材料の平衡含水率測定方法-に規定されているが文18)、 新たな水蒸気吸着等温線の測定法の一つとしての有効性も検郡する。 その後、MSB および吸着破過試験にて水蒸気存在下でのホルムアル デヒドの吸着等温線を測定した結果を示し、室内化学物質空気污染 が問題となる比較的低濃度域での実用性を検討する。

\section{2. 吸着量測定方法概要}

吸着等温線は、等温状態で吸着材に吸着される質量を測定するこ とにより得られる。この原理により測定を行なうものに重量法があ る文19)。これは吸着材を被吸着物質の蒸気中で平衡させ、その重量
* 吉野石膏(秼) 工修

** 東京大学生産技術研究所 教授 $\cdot$ 工博

****東京大学大学院 大学院生

**** 東京大学生産技術研究所 博士研究員 - 博士 (工学)

***** (䨀化分析センター
Yoshino Gypsum Co., Ltd., M. Eng.

Prof., Institute of Industrial Science, Univ. of Tokyo, Dr. Eng.

Graduate Student, Tokyo University

Institute of Industrial Science, Univ. of Tokyo, Ph. D.

Sumika Chemical Analysis Service Co., Ltd. 
測定により吸着量を求める。これは大気中の成分 $\left(\mathrm{O}_{2}, \mathrm{~N}_{2}\right.$ など) の 吸着が無視できる場合に気中に一定濃度の被吸着ガス成分を混合し、 その重量を測定する方法で行なわれる。これは測定を大気圧下で行 なうことができ、便利な方法となる。吸着材の吸着は、一般に大気 压下の空気中の雰囲気での値が問題となるため、吸着等温線の測定 は、このような状況下での直接測定が望ましいと考えられる。

\section{1 磁気浮遊天秤（MSB）を用いた吸着等温線測定法}

磁気浮遊天秤を用いた方法は、大気圧下で温度一定で一定湿度の 空気もしくはそうした調整空気中に HCHO ガスを一定浱度混合し たものを磁気浮遊天秤のサンプルセルに一定量流通させる。吸着に よる重量変化を吸着平衡にいたるまで直接測定することで、建材. 吸着材に対する吸着量（吸着等温線）を測定する方法である。測定 に使用する磁気浮遊天秤を図 1 に示し、基本仕様を表 1 に示す。磁 気浮遊天秤の最大の特徵は、重量変化を無接触磁気浮遊状態により 測定できることである。重量測定部 (天秤) がサンプルセルと切り 離され、気流や外部振動によるゆらぎがなく、測定需囲気にさらさ れていないため、腐食性ガスにも対応可能な重量変化測定システム となっている。

\section{2 吸着破過試験法}

同じく大気圧下での吸着材の吸着量測定方法のひとつに、吸着破 過試験がある文 20-23)。これは吸着材を粉砕し、ガラス管などに充填 した吸着材充填層に一定温度、一定濃度、一定流量の污染ガスを含 む流体を供給し、吸着量を求める方法である。吸着破過試験装置図 を図 2 に示寸。充填層内での吸着は、流体流れ中の吸着質（污染物 質）の軸方向拡散（吸着により流れ方向に滣度が低下し、泱度差に よる物質移動、つまり分子拡散が生じる）および流体流れから吸着 材表面への物質移動速度に影響を受ける。後者の物質移動速度は、 吸着材粒子近傍の境膜物質移動（境界層における物質移動）と吸着 材粒子内の拡散抵抗の二つ要因で決定される。流れが極めて遅い場 合の充填層内の流体の流れは層流となり、流体境膜（境界層）は考 えにくいので、層流域 (低流速) で試験を行なうことが重要である。 図 3 に示寸ように、ある時間が経過すると、入口からある点までが、 (1) 吸着平衡に達した部分、(2) 吸着が進行している部分 (吸着帯)、 (3) 未吸着層部分に分けられる。(2)の吸着帯は、流通時間（流通量） とともにしだいに下流側に移っていく。したがって、出口での污染 ガスの濃度を測定すると、一般に時間に対し $\mathrm{S}$ 字状の曲線が得られ る。出口における污染ガス成分の濃度と時間との関係を破過曲線と よぶ。また、図 3 の点 $B_{1}$ の濃度に達したときを破過点といい、点 $B_{1}$ における濃度 $C_{\mathrm{B}}$ を破過濃度とよぶ。このときの、吸着量 $B$ は、 式(1)となるメ201。

$$
B=\frac{C \times F \times t}{1000 \times M}
$$

ここで、 $B$ :吸着量 $[\mu \mathrm{g} / \mathrm{g}], C:$ 入口濃度 $\left[\mu \mathrm{g} / \mathrm{m}^{3}\right], F:$ 流量 $[l / \mathrm{min}]$, $t$ :破過濃度 $C_{\mathrm{B}}$ 到達時間 $[\mathrm{min}], M$ :試料質量 $[\mathrm{g}]$ である。

\section{3. 測定方法}

\section{1 測定試料および試験項目}

表 2 に測定試料および試験項目を示す。せっこうボード（GB） などの一般的な建築材料および調湿建材を対象とした。吸着材と して活性炭（AC）のほか、室内污染空気を浄化するといわれてい

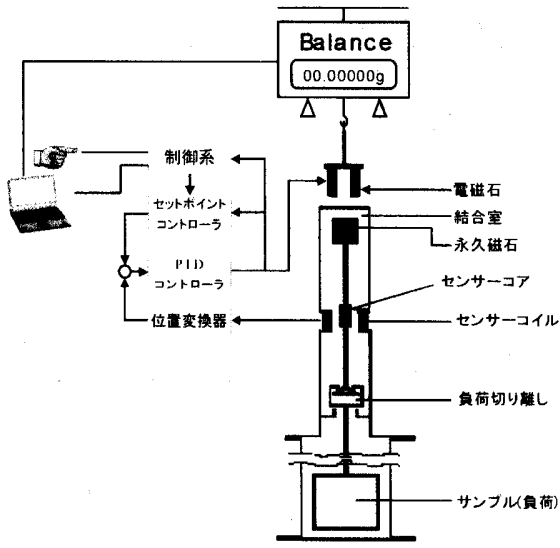

図 1 磁気浮遊天秤 (MSB)

表 1 MSB $の$ 装置基本仕様

\begin{tabular}{ll}
\hline 使用ガス & $\mathrm{H}_{2} \mathrm{O} / \mathrm{Air}$ or $\mathrm{HCHO}(\mathrm{VOCs}) / \mathrm{Air}$ \\
最大サンプル量 & $15 \mathrm{~g}$ 以下 \\
重量測定分解能 & $10 \mu \mathrm{g}$ \\
重量測定再現性 & $\pm 20 \mu \mathrm{g}$. \\
\hline
\end{tabular}

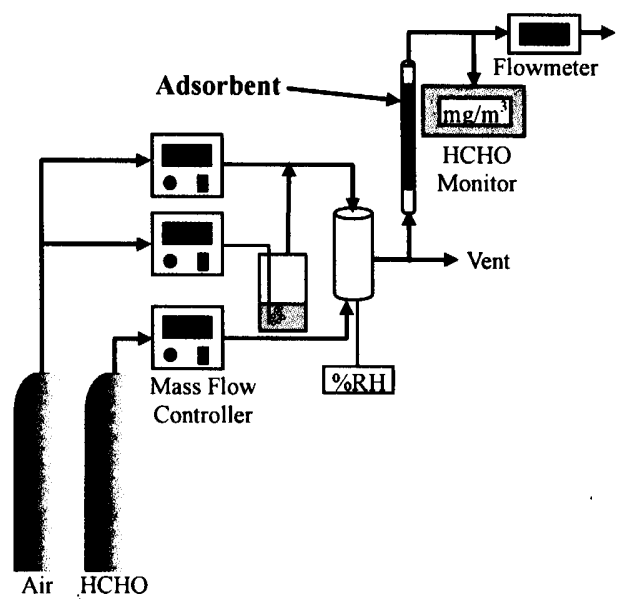

図 2 吸着破過試験装置

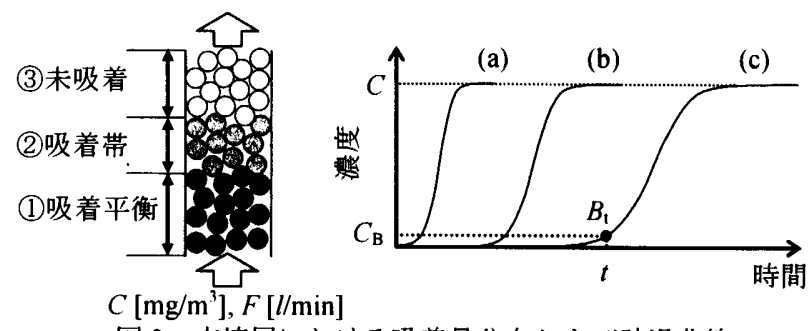

図 3 充填層における吸着量分布および破過曲線

表 2 測定試料および武験項目

\begin{tabular}{llccc}
\hline \multirow{2}{*}{ 測定試料 } & 記号 & \multicolumn{2}{c}{ MSB } & 破過試験 \\
& & 水蒸気 & HCHO & HCHO \\
\hline \hline せっこうボード & GB & $\bigcirc$ & $O$ & $\bigcirc$ \\
ロックウール(天井板) & RW & $\bigcirc$ & $\times$ & $\times$ \\
ケイカル板 & CSB & $\bigcirc$ & $\times$ & $\times$ \\
珪藻土入りせっこうプラスター & DGP & $\bigcirc$ & $\times$ & $\times$ \\
吸放湿性せっこうボード & SGB & $\bigcirc$ & $\times$ & $\times$ \\
多孔質セラミックス調湿建材 & HPC & $\bigcirc$ & $\times$ & $\times$ \\
活性炭(試薬) & AC & $\bigcirc$ & $\times$ & $\bigcirc$ \\
備長炭 & BC & O & $\times$ & $\bigcirc$ \\
竹炭 & TC & $\bigcirc$ & $\times$ & $\bigcirc$ \\
HCHO 吸収分解せっこうボード & HGB & $\times$ & $\times$ & $\bigcirc$ \\
\hline
\end{tabular}


る備長炭（BC）や竹炭（TC）を試料とした。またパッシブ吸着建 材として、HCHO 吸収分解せっこうボード（HGB）を試料とした神 $1)$

\section{2 測定条件}

\subsubsection{MSB による水蒸気吸着等温線}

表 3 に測定条件を示す。測定温度は $23^{\circ} \mathrm{C}$ とし、相対湿度は $0 \sim 90 \%$ の範囲とした。湿度の設定は、MSB 内で加湿空気と乾燥空気の混合 により行なう。また、測定時には MSB 装置内の湿度計による実測 值が設定值の $\pm 0.2 \%$ 範囲となるよう混合比が自動フィードバッ ク制御される。湿度計の精度は土 $2 \% \mathrm{RH}$ である。測定試料は $1 \mathrm{~mm}$ 以 下に粉砕して測定を行なった ${ }^{\text {il:2)。 }}$

\subsubsection{MSB による $\mathrm{HCHO}$ 吸着等温線}

GB の原紙を取除き、芯材であるせっこう部分のみを $1 \mathrm{~mm}$ 以下に 粉砕した ${ }^{2)}$ 。測定温度は $23^{\circ} \mathrm{C}$ とし、相対湿度はできる限り水蒸気 吸着の影響が少ない $2.5 \%$ とした（表 3)。HCHO は $50 \mathrm{ppm}\left(\mathrm{N}_{2}\right.$ ベー ス）を純空気（G1 Grade）で所定濃度に希釈した。

\subsection{3 吸着破過試験による $\mathrm{HCHO}$ 吸着等温線}

試料を $0.5 \sim 1.0 \mathrm{~mm}$ に粉砕し注 2 、内径 $6.0 \times 10^{-3} \mathrm{~m}$ 、長さ $2.0 \times 10^{-1} \mathrm{~m}$ のパイレックス製ガラス管に充填した。ガラス管の両端には、試料 を押さえるために石英ウールを充填した湆3)。測定条件を表 4 に示す。 温度は $28^{\circ} \mathrm{C}$ とした。試料の水蒸気吸着の影響を避けるため、相対湿 度は水分除去装置通過後の $11 \sim 12 \%$ とした。HCHO は $20 \mathrm{ppm}\left(\mathrm{N}_{2}\right.$ ベース）を清浄空気で所定濃度に希釈した。設定流速（流量）なら びに破過濃度 $C_{\mathrm{B}}$ は、ASTM D 6646 - 01 を参考とし文20)、 $\mathrm{v}=4.78 \times 10^{-2}$ $\mathrm{m} / \mathrm{s} \quad(F=0.081 / \mathrm{min})$ ならびに入口濃度 $C$ に対して $0.5 \%$ 破過時の濃度 とした。はじめに、活性炭（AC）を用いて吸着破過試験による吸着 量のバラツキの確認試験を行なった。その後、表 2 に示寸各試料の 吸着破過試験を行なった。ただし、GB, HGBに関しては、原紙あり （記号：P）と原紙なし（芯材のせっこうのみ）の条件で試験を行 なった。

\section{3 測定方法}

\subsubsection{MSB による水蒸気吸着等温線}

乾燥後の試料を MSB に設置し、表 3 の測定条件で水蒸気吸着量 測定を開始寸る。一定温度で MSB のサンプルセル部分に設定相対 湿度に調整された空気を流通させ、吸着平衡に到達するまで重量測 定を繰り返す。平衡重量に到達後、順次設定湿度での吸着平衡量を 求め吸着等温線を測定寸る。同様に脱着等温線の測定も行う。

\subsubsection{MSB による HCHO 吸着等温線}

3.3.1 と同様、MSBに試料設置後、表 3 の条件で $\mathrm{HCHO}$ 吸着量測 定を開始する。はじめに設定相対湿度 $2.5 \%$ で平衡重量とさせる。水 蒸気吸着平衡到達後、順次設定 $\mathrm{HCHO}$ 濃度での平衡吸着量を求め、 $\mathrm{HCHO}$ 吸脱着等温線を測定する（相対湿度は $2.5 \%$ 一定）。

\subsection{3 吸着破過試験}

試料をガラス管に充填後、所定濃度の $\mathrm{HCHO}$ ガスを供給する。試 料質量 $M$ 、入口濃度 $C$ 、破過濃度 $C_{\mathrm{B}}$ 、破過時間 $t$ を測定し、吸着量 $B$ を求める。入口 $\mathrm{HCHO}$ 濃度の測定は DNPH カートリッジにより空 気捕集し、高速液体クロマトグラフ（HPLC）により定量する。ま た、出口側の $\mathrm{HCHO}$ 濃度は $C_{\mathrm{B}}$ を検出するために連続測定する必要 がある。そのため、連続測定可能な $\mathrm{HCHO}$ 簡易測定器を使用する。 本試験に使用した HCHO 簡易測定器は、定電位電解法を原理として
表 3 MSB 測定条件注4)

\begin{tabular}{lcc}
\hline & 水蒸気 & HCHO \\
\hline \hline 温度 $\left.{ }^{\circ} \mathrm{C}\right]$ & 23 & 23 \\
相対湿度[\%] & $0 \sim 90$ & 2.5 \\
湿度平衡判断値[\%] & \pm 0.2 & \pm 0.2 \\
重量平衡判断値[g/s] & $10^{-6} / 120$ & $10^{-6} / 3600$ \\
重量平衡時間[s] & 3600 & 3600 \\
\hline
\end{tabular}

表 4 吸着破過試験測定条件

\begin{tabular}{ll}
\hline 温度 $\left[{ }^{\circ} \mathrm{C}\right]$ & 28 \\
相対湿度[\%] & $11 \sim 12$ \\
流速 $\mathrm{v}[\mathrm{m} / \mathrm{s}]$ (流量 $F[l / \mathrm{min}])$ & $4.78 \times 10^{-2}(0.08)$ \\
破過濃度 $C_{\mathrm{B}}$ & 入口濃度 $C$ に対し $0.5 \%$ 破過時の濃度 \\
\hline
\end{tabular}

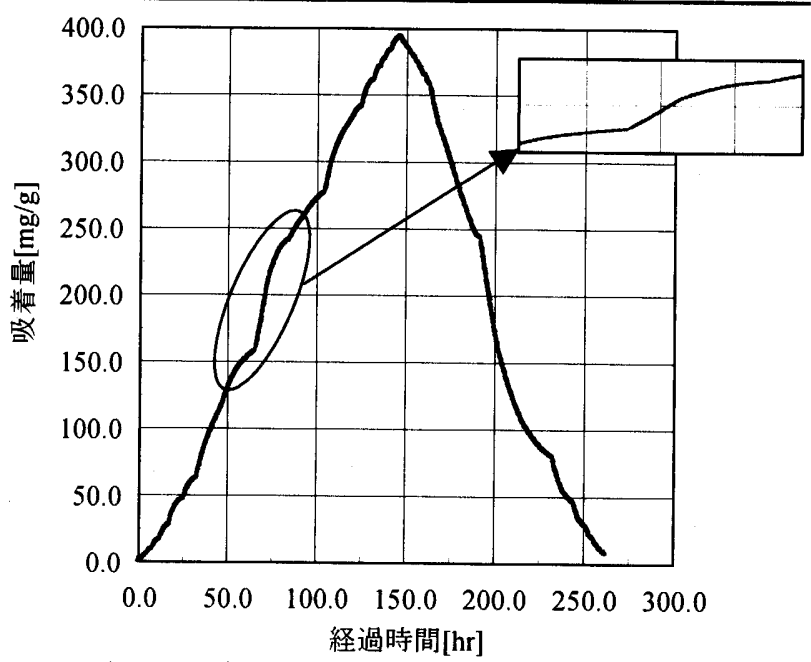

図 4 測定経過時間と吸着量の変化 (AC)

いる注5)。一般に簡易測定器は、共存ガスの影響を多大に受けるので、 吸着破過試験を行なう前にDNPH との相関関係を確認している。

\section{4. 実験結果および考察}

\subsection{MSBによる水蒸気吸着等温線}

図 4 に測定経過時間と吸着量の変化の例として、活性炭 (AC) の 場合を示す。図 4 右上の拡大図からもわかるように、ある相対湿度 で吸着平衡に到達した後に、次の相対湿度条件での測定が行なわれ ていることが確認できる。

各試料の水蒸気吸着等温線の測定結果を図 5 (a) 〜 (i)に示す。全て の試料で吸着等温線と脱着等温線が等しくならないヒステリシス現 象を示した。活性炭（AC：図 5(g)）および竹炭（TC：図 5(i)）は、 文献とほぼ同じ水蒸気吸着特性 (等温線) が得られた文 24,25)。これ より、MSBによる水蒸気吸着等温線の測定は妥当なものと考えられ、 水蒸気吸着等温線測定法としては有効である。

$\mathrm{AC}$ は他の試料よりも水蒸気吸着量が非常に大きいことがわかっ た。AC は相対湿度 $50 \%$ 前後で急激に水蒸気吸脱着量が変化した。 一方、せっこうボード（GB : 図 5(a)）は測定試料中で最も水蒸気吸 着量が少なかった。しかしながら少ないというものの、相対湿度 $90 \%$ 時の吸着量は約 $20 \mathrm{mg} / \mathrm{g}$ ある。このように水蒸気吸着量が少ない材 料でも、污染化学物質吸着量測定を行なう場合は、水蒸気吸着の影 響に注意が必要なことを示唆している。また、各建材は相対湿度が $70 \%$ 程度から吸着量が増加する傾向がみられた。特に調湿建材は、 高湿度域での吸着量の増加が顕著にみられた（図 5(d)〜 (f))。これは 調湿建材に配合されている珪藻土などの吸放湿材料の特性のためと 


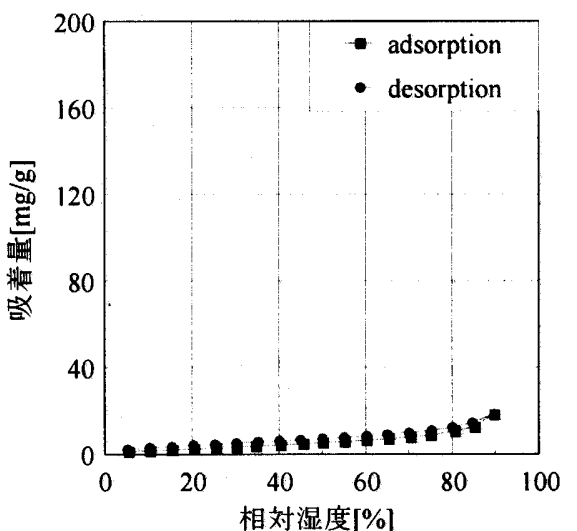

(a) GB

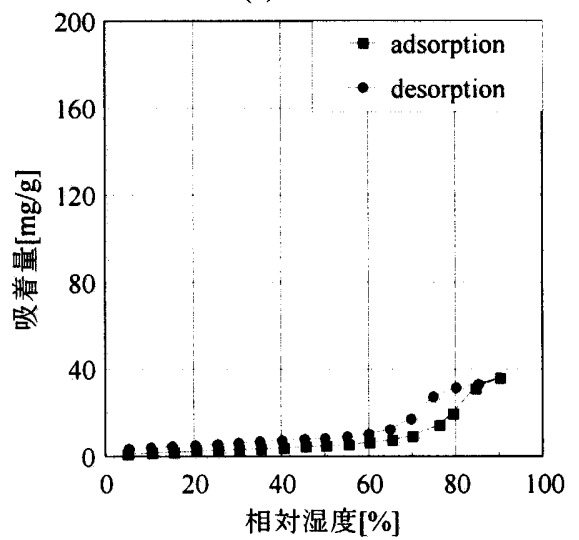

(d) DGP

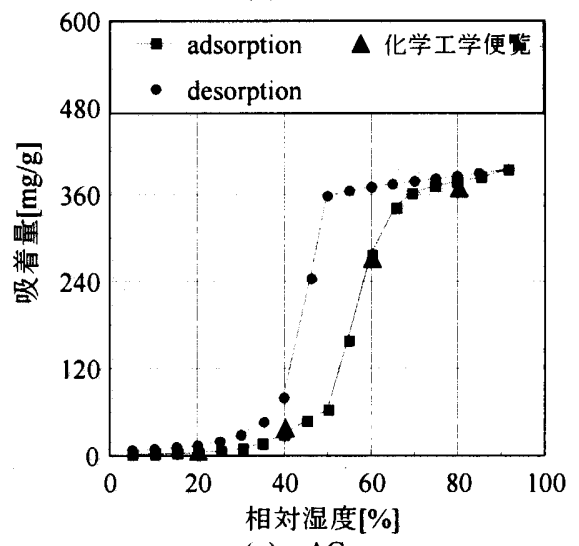

(g) $\mathrm{AC}$

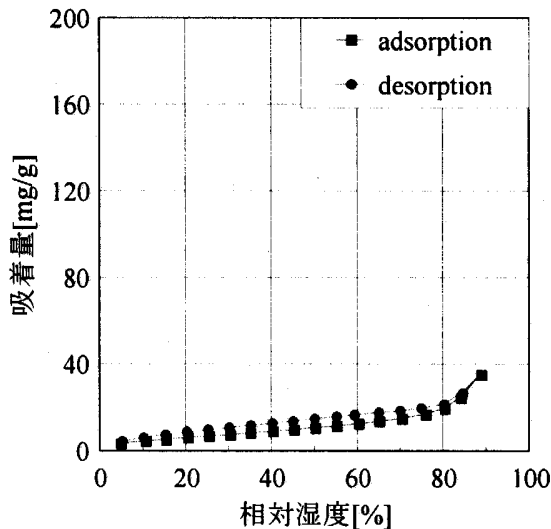

(b) $\mathrm{RW}$

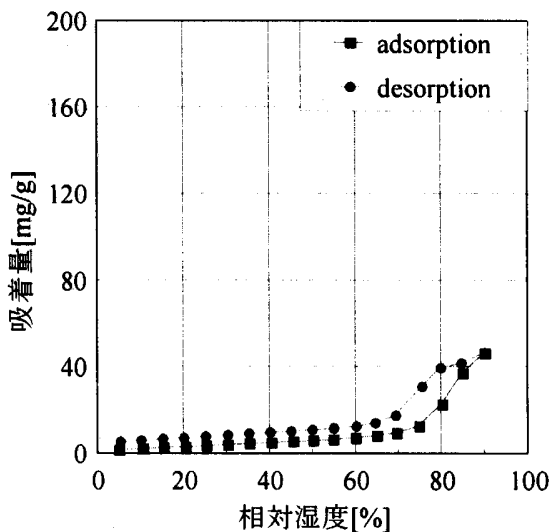

(e) SGB

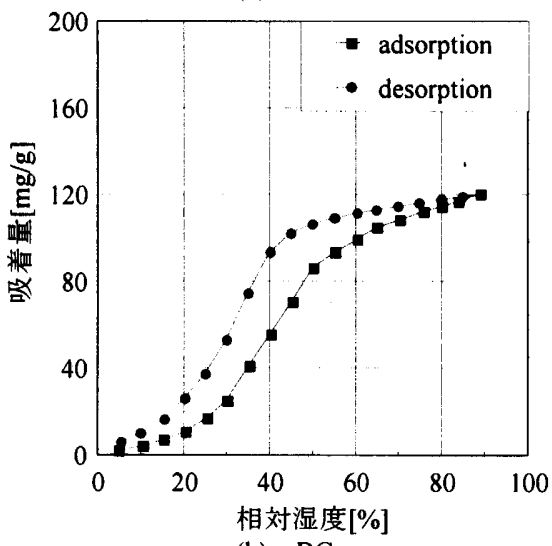

(h) $\mathrm{BC}$

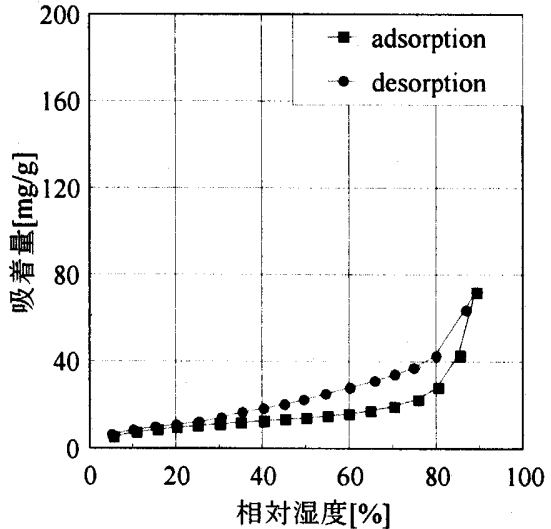

(c) CSB

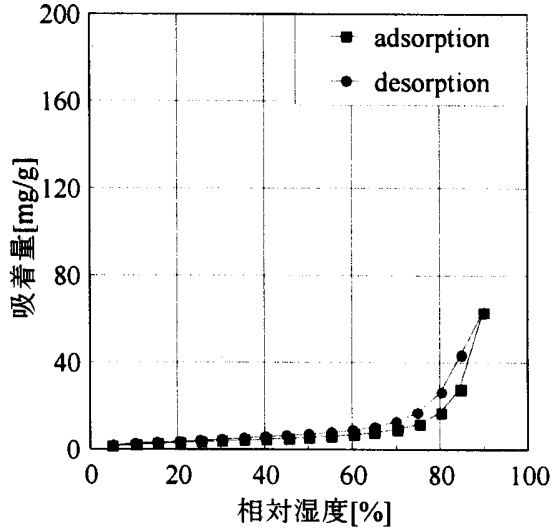

(f) $\mathrm{HPC}$

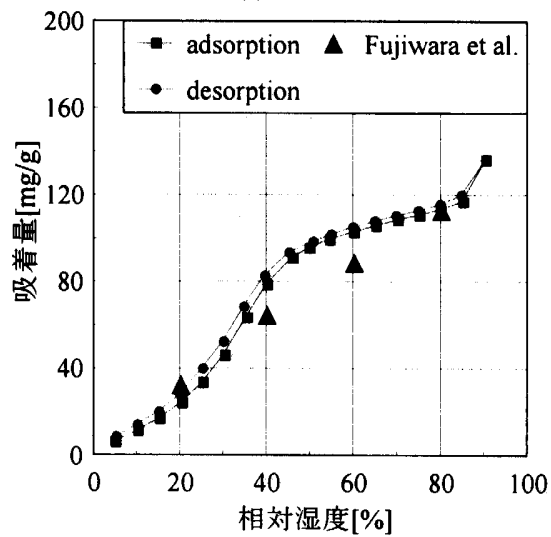

(i) $\mathrm{TC}$

図 5 MSB による水蒸気吸着等温線

考えられる。備長炭（BC：図 5(h)）およびTC といった炭化物を用 いた吸着材は $\mathrm{AC}$ と異なり、低湿度域から水蒸気吸着量が増加する 傾向があった。ただし、BCや $\mathrm{TC}$ の場合、 $\mathrm{AC}$ のうに工業製品で はない。製造者毎により炭化温度や細孔分布などの性状が異なるな ど品質が一定でない可能性があり、常に同じ吸着性能を有するかは 不明である。今後、様々な炭類を測定し、統計的に吸着特性を検討 する必要がある。

以上、水蒸気吸着等温線の測定結果より、mg/g オーダーの水蒸気 が吸着することから、重量変化より污染化学物質の吸着量を求める 方法は、水蒸気の影響に十分注意する必要がある。すなわち、污染 化学物質吸着量が水蒸気吸着量を無視できるほど大きくない限り、 重量変化から污染化学物質吸着量を测定することは不可能となる。

\subsection{MSB による HCHO 吸着等温線}

図 6 に GB $の \mathrm{HCHO}$ 吸着等温線を示す。 $\mathrm{HCHO}$ 吸着等温線测定に は1ヶ月以上の非常に長期間を要した。等温線はヒステリシス現象 が見られ、脱着時に初期重量に戻らない現象が見られた。この原因 として、吸着されたホルムアルデヒドの一部が GB 内に含有される 微量金属元素などの触媒作用によって分解されるなど、材料内で化 学的に固定化されてしまっていることも考えられる。しかし、原因 の特定ができておらず、今後の検討課題である。また図 5(a)より、 $\mathrm{GB}$ は他の試料よりも水蒸気吸着量が少ないものの $\mathrm{mg} / \mathrm{g}$ オーダーあ る。一方 $\mathrm{HCHO}$ 吸着量は $\mu \mathrm{g} / \mathrm{g}$ オーダーである。これより $\mathrm{HCHO}$ 吸 着量測定に際し、水蒸気吸着量の変動が大きく影響し、 $\mathrm{HCHO}$ 吸着 量の測定が困難な場合があることを示唆している。すなわち、HCHO 吸着量に対し水蒸気吸着量が無視できない場合、重量変化から 
$\mathrm{HCHO}$ 吸着量を測定することは不可能となる。今回の GB の測定で は HCHO 吸着量が少なく測定が困難であり、今後 $\mathrm{HCHO}$ 吸着量が 多いと思われる材料に関して検討する必要がある。

\section{3 吸着破過試験による $\mathrm{HCHO}$ 吸着等温線}

図 7 に DNPH カートリッジによる HCHO 濃度と HCHO 簡易測定 器による HCHO 濃度との関係を示す。本研究で用いた HCHO 簡易 測定器は、DNPH との直線関係が得られ、共存ガスが存在しなけれ ばHCHO 濃度のモニタリングには十分使用可能と判断した。

表 5 に活性炭 $(\mathrm{AC})$ の吸着量 $B$ のバラツキ試験の結果を示す。設 定流速（流量）は ASTM D 6646-01 の設定値 $\mathrm{v}=4.78 \times 10^{-2} \mathrm{~m} / \mathrm{s}$ $(0.081 / \mathrm{min})$ よりやや大きいものの、 $\sigma_{\mathrm{n}-1}$ が $0.08 \times 10^{-2} \mathrm{~m} / \mathrm{s}$ と試験毎の バラツキは小さかった。また、試験中の流速変動は見られなかった。 しかし、より安定した試験を行うためには、今後試験毎の流速が一 定となるよう装置の改良も必要と思われる。吸着量 $B$ の $\sigma_{\mathrm{n}-1}$ も 5.2 $\mu \mathrm{g} / \mathrm{g}$ と小さく、試験毎のバラツキはあまりないと考えられる。

吸着破過試験による破過曲線の一例を図 8 に示し、HCHO 吸着等 温線を図 9 (a) (f)に示す。吸着破過試験は測定時間が比較的短時間 であり、吸着量測定法としては簡便な試験法と考えられる。

パッシブ吸着建材である HCHO 吸収分解せっこうボード（HGB： 図 9(e)）は、せっこうボード（GB 図 9(d)）に比べ HCHO 吸着量が 非常に大きかった。原紙を含有した試験（記号：P）では、原紙を 含まない場合よりもわずかに吸着量が増加する傾向があった。 $\mathrm{HGB}$ は化学吸着が支配的であるため、HCHO 濃度に対する飽和吸着量に 大きな変化はなかった。竹炭（TC）の $\mathrm{HCHO}$ 吸着量は、他の試料 よりも非常に大きかった。これは TC の細孔分布特性だけでなく、 TC 中に含有している成分元素が吸着に大きく影響していると思わ れる。藤原らは炭化物中の元素分析を行なっているが文25)、竹類は 樹木類に比べ、K（カリウム）ならびに Mg（マグネシウム）を多く 含み、Ca（カルシウム）分は樹木類と同程度含有されていることを 報告している。特に竹炭は $\mathrm{K}$ 分が多く、弱アルカリ性を示すとして いる。ホルムアルデヒドはアルカリを作用させると、カニッツァロ 反応といわれる反応を起こし、ギ酸とメタノールを生成することが 知られている。また、塩基触媒で数分子が重合して糖の混合物（モ ルホース）が得られるとされている文26)。これらの反応によっても TC の吸着量が増加している要因の一つと思われるが、他の要因も 考えられるので、今後数種類の TC での測定を行い、吸着量増加の 要因を検討寸る必要がある。一方、本研究で用いた備長炭 (BC) は、 $\mathrm{GB}$ と同程度に吸着量が小さかった。

ここで、厚生労働省指針値である $100 \mu \mathrm{g} / \mathrm{m}^{3}$ 時の $\mathrm{HCHO}$ 吸着量予 測値を求めると、表 6 となる。吸着破過試験より $\mathrm{HCHO}$ 吸着量を求 める方法は、出口濃度を計測するための簡易測定器の検出下限値が $10 \mu \mathrm{g} / \mathrm{m}^{3}$ のため、ある程度入口濃度を高濃度とした条件で試験を行 ない、破過濃度 $C_{\mathrm{B}}$ を計測することになる。その結果から吸着等温式 などを利用し、室内化学物質污染が問題となっている低濃度域での 吸着量を予測することになる。この際、物理吸着支配の試料は、

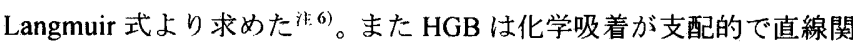
係が得られるので、 $100 \mu \mathrm{g} / \mathrm{m}^{3}$ 時の吸着量は外挿して求めた。 HGB の $100 \mu \mathrm{g} / \mathrm{m}^{3}$ 時の吸着量 $B$ を求めると、60 70 $\mu \mathrm{g} / \mathrm{g}$ となった。こより、 $100 \mu \mathrm{g} / \mathrm{m}^{3}$ 時の吸着量は化学吸着する $\mathrm{HGB}$ が大きく、物理吸着支配 の場合は、10 $\mathrm{g} / \mathrm{g}$ 以下と予測された。

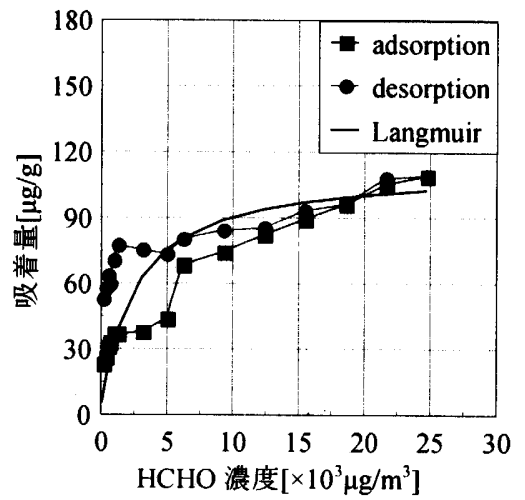

図 6 MSB による HCHO 吸着等温線

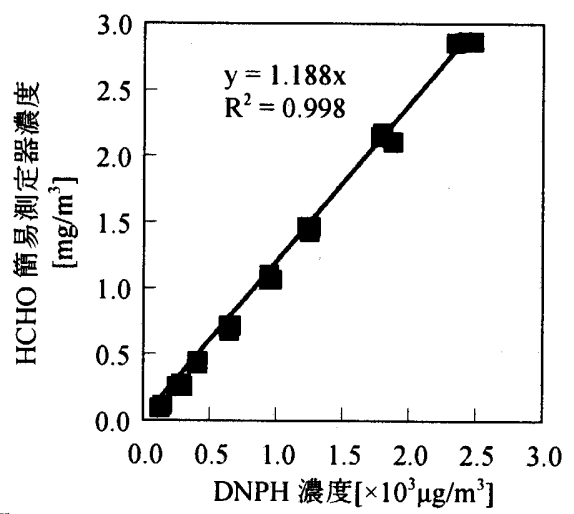

図 7 DNPH カートリッジと HCHO 簡易測定器の関係

表 $5 \mathrm{AC}$ の吸着量 $B$ のバラツキ試験結果

\begin{tabular}{ccccc}
\hline No. & $\begin{array}{c}\text { 流速 } \mathrm{v} \\
{\left[\times 10^{-2} \mathrm{~m} / \mathrm{s}\right]}\end{array}$ & $\begin{array}{c}\text { 流量 } F \\
{[l / \mathrm{min}]}\end{array}$ & $\begin{array}{c}\text { 入口濃度 } C \\
{\left[\times 10^{3} \mu \mathrm{g} / \mathrm{m}^{3}\right]}\end{array}$ & $\begin{array}{c}\text { 吸着量 } B \\
{[\mu \mathrm{g} / \mathrm{g}]}\end{array}$ \\
\hline \hline 1 & 5.01 & 0.085 & 3.55 & 97.0 \\
2 & 4.83 & 0.082 & 3.74 & 92.3 \\
3 & 4.83 & 0.082 & 3.87 & 104.4 \\
4 & 4.83 & 0.082 & 3.83 & 99.2 \\
5 & 4.89 & 0.083 & 3.95 & 92.0 \\
\hline 平均 & 4.88 & 0.083 & 3.79 & 97.0 \\
$\sigma_{\mathrm{n}-1}$ & 0.08 & 0.001 & 0.15 & 5.2 \\
\hline
\end{tabular}

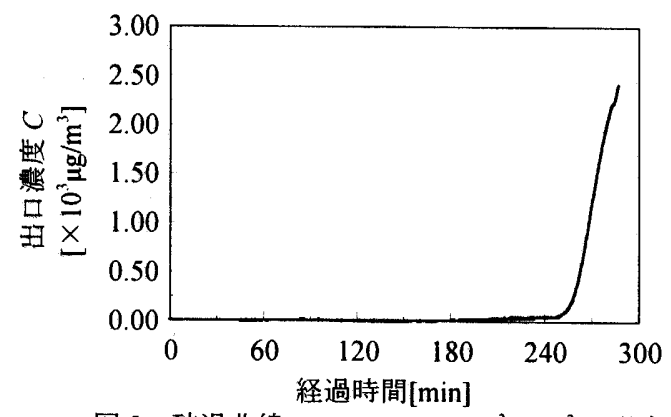

図 8 破過曲線(HGB, C $=6.49 \times 10^{3} \mu \mathrm{g} / \mathrm{m}^{3}$ の場合)

また、吸着破過試験での GB の吸着量はMSBに比べ、非常に小さ かった。これは水蒸気吸着の影響の有無があったためと思われる。 このように MSB のような重量変化で HCHO の吸着量を測定するに は、水蒸気吸着の影響が無視できずに HCHO 吸着量の測定が困難な 場合がある。一方吸着破過試験では、出口濃度を計測することによ って吸着量を求めるので、水蒸気による吸着量変化の影響を受けに くく、奏験手順も簡単であり、比較的短時間で测定が行なえること から、実用的な測定法である。 

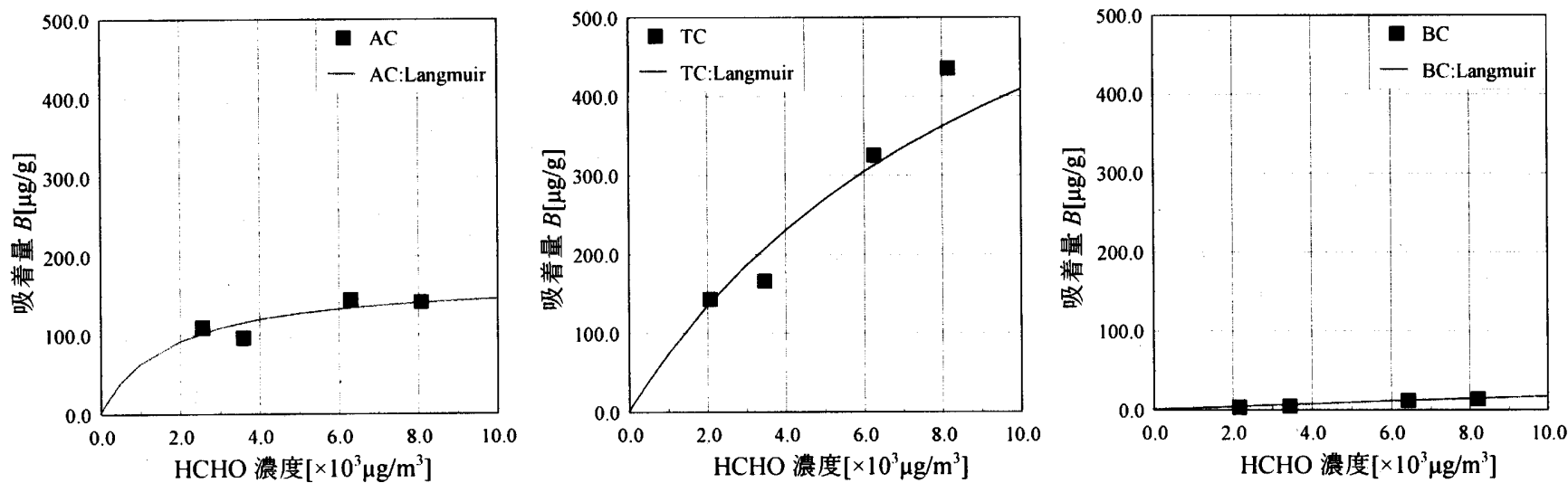

(a) $\mathrm{AC}$
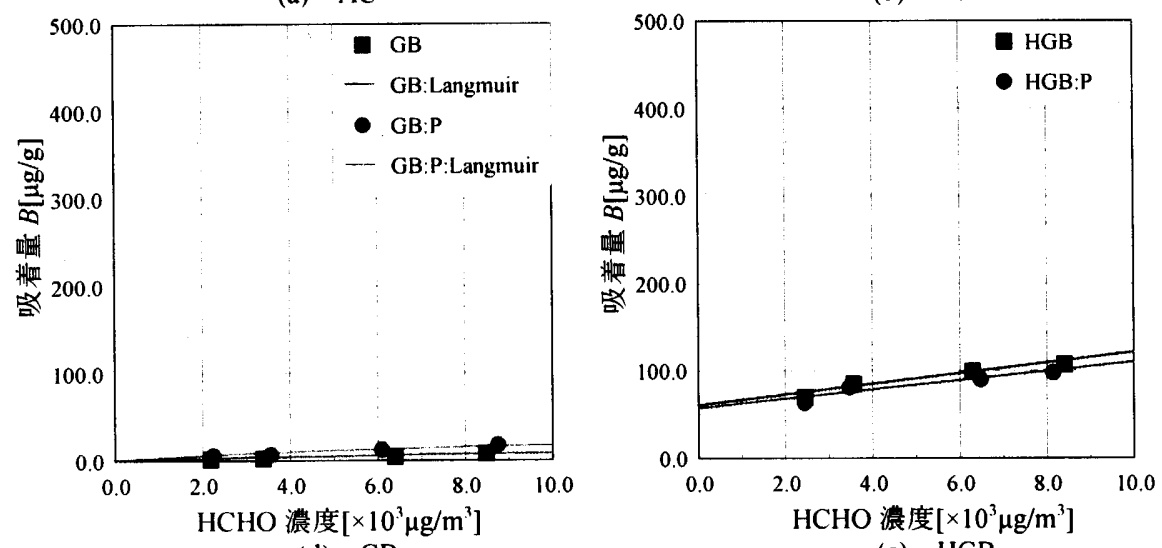

(c) $\mathrm{BC}$

(d) GB

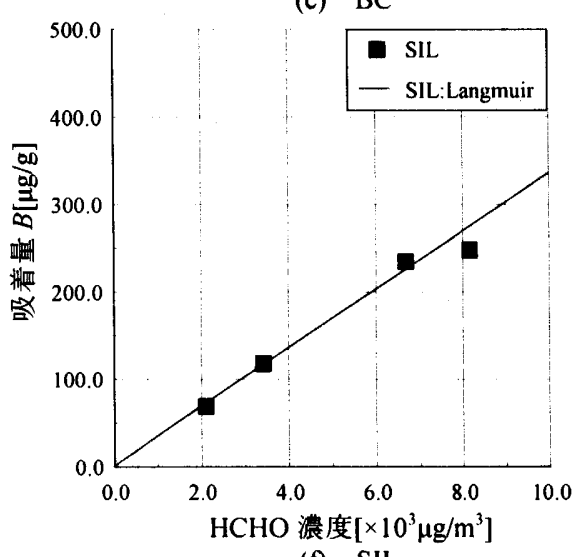

(f) SIL

図 9 吸着破過試験による $\mathrm{HCHO}$ 吸着等温線

\section{5. 結論}

磁気浮遊天秤を用いた吸着装置（MSB）による試験および吸着破過 試験により、建築材料、吸着材の水蒸気および HCHO の吸着等温線 を測定し、基礎的な検討を行なった。MSBによる吸着等温線測定で は、

(1) 水蒸気吸着等温線は、他の測定例と比較して十分に測定可能な ものであった。これより、MSB を用いた水蒸気吸着等温線測定 法は、有用な測定法である。また、他の建築材料などに対して MSB での水蒸気吸着等温線測定を行なえば、有用な基礎的デー タとなる。

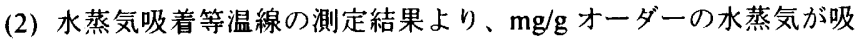
着することから、重量変化より污染化学物質の吸着量を求める 方法は、水蒸気の影響に十分注意する必要がある。すなわち、 污染化学物質吸着量に対し水蒸気吸着量が無視できない限り、 重量変化から污染化学物質吸着量を測定することは不可能であ る。

(3) 吸着等温線と脱着等温線が等しくならないヒステリシス現象を 示した。

（4）活性炭の水蒸気吸着量は大きく、相対湿度 $50 \%$ 程度から急激に 吸着量が増加した。また、各建材は相対湿度が約 $70 \%$ 付近から 水蒸気吸着量が増加した。

また、吸着破過試験での $\mathrm{HCHO}$ 吸着等温線測定では、

(5) 出口濃度を計測することによって吸着量を求めるので、水蒸気 による吸着量変化の影響を受けにくく、実験手順も簡単である。 また、比較的短時間で測定が行なえるので、実用的な測定法で
表 6 各試料の $100 \mu \mathrm{g} / \mathrm{m}^{3}(0.08 \mathrm{ppm})$ 時の HCHO 吸着量予測值

\begin{tabular}{lccccc}
\hline \multirow{2}{*}{$\begin{array}{c}\text { 試料名 } \\
\end{array}$} & $\begin{array}{c}\text { 吸着量 } B[\mu \mathrm{g} / \mathrm{g}] \\
\left(100 \mu \mathrm{g} / \mathrm{m}^{3} \text { 時 }\right)\end{array}$ & \multicolumn{2}{c}{ Langmuir 係数 } & \multicolumn{2}{c}{ 回㷌直線係数 } \\
\hline $\mathrm{AC}$ & 9.4 & 0.17 & $K_{\mathrm{L}}$ & $a$ & $b$ \\
$\mathrm{TC}$ & 7.8 & 0.085 & 0.093 & - & - \\
$\mathrm{BC}$ & 0.2 & 0.15 & 0.013 & - & - \\
$\mathrm{GB}$ & 0.1 & 0.027 & 0.038 & - & - \\
$\mathrm{GB}: \mathrm{P}^{*}$ & 0.3 & 0.037 & 0.080 & - & - \\
$\mathrm{HGB}$ & 60.2 & - & - & 6.03 & 59.5 \\
$\mathrm{HGB}: \mathrm{P}^{*}$ & 68.9 & - & - & 5.26 & 56.1 \\
SIL & 3.4 & 19.18 & 0.0018 & - & - \\
\hline
\end{tabular}

*P:原紙ありの場合

※ 物理吸着:Langmuir 式より算出, 化学吸着(化学反応):外挿

ある。

(6) ある程度高濃度域での吸着等温線を測定し、吸着等温式などか ら室内化学物質空気污染が問題となる比較的低濃度域での吸着 量を予測することができる。

(7) 吸着量 $B$ などのバラツキ確認の基礎的検討を行なった結果、試 験毎の流速のバラツキは小さく、実験中の流速変動も見られな かった。また、試験間の吸着量 $B$ のバラツキも小さかった。

(8) 竹炭の HCHO 吸着量は大きかった。これは細孔分布特性だけで なく含有元素などによる影響のため、吸着量が増加したと思わ れる。

（9）今回測定した試料の厚生労働省指針值での吸着量予測値は、物 理吸着を原理とする試料では約 $10 \mu \mathrm{g} / \mathrm{g}$ 以下、化学吸着を原理と する試料では $60 \sim 70 \mu \mathrm{g} / \mathrm{g}$ と予測された。 
6. 今後

(1) 様々な建築材料、吸着材を対象として、水蒸気吸着等温線なら びに HCHO や他の化学物質（例えばトルエン）の吸着等温線を 測定する。

(2) MSB による GB の HCHO 吸着等温線測定で、脱着時に初期重量 に戻らない現象が見られた原因の検証が不十分である。どのよ うなメカニズムでこの現象が生じるのか検討が必要である。

(3) 竹炭の吸着量が大きかった原因が十分に解明されていないので、 今後の課題である。

\section{謝辞}

本研究は、独立行政法人 新エネルギー・産業技術総合開発機構 （NEDO）の委託を受け、財団法人 建材試験センター内に設置され た「建材からのVOC 等放散量の評価方法に関寸る標準化委員会 吸 着分解低減化部会 (委員長:加藤信介 東京大学生産技術研究所教 授）」の研究活動の一部として行われている。また、日本建築学会特 別調査委員会・シックハウス問題の解明とヘルシーな居住環境の開 発特別研究委員会 (委員長:村上周三 慶応義塾大学理工学部教授) および国土交通省 建設技術研究開発費補助金·室内化学物質空気污 染の事前評価と健康影響防止技術の開発（研究代表者:加藤信介 東 京大学生産技術研究所教授）の活動の一環としても実施されたもの である。関倸各位に深甚なる謝意を表する次第である。

注

|1| 試験体はメーカーから直接入手、あるいは建材店より入手した。メ一カ 一から入手の場合、製造直後の製品を無作為に抽出している。試験体は アルミホイルで包み、さらにビニル袋で密閉した状熊で輸送·保存してい る。活性炭は試薬、備長炭・竹炭は DIY ショッブにて市販品（室内空気を 浄化すると表記）を入手した。

|2| 試料を粉砕寸る際、二次構造が破壊されない程度の粉砕とし、微粉は除 去した。また、各試料は含水があるため、加熱乾燥を行ない、その後乾 燥剤を入れたデシケータ中に保存した。ただし、加熱乾燥する場合、加 熟により結晶構造が変化してしまう試料もあるため、乾燥条件は必ずし も同じではない。

|3|あらかじめガラス管および石英ウールに対し、HCHO 吸着の影響がない ことを確認している。

[4| 表 3 で使用した用語を以下に説明する。 湿度平衡判断値：設定相対湿度に対し、実際の測定湿度の許容範囲。設 定の相対湿度に対し、この值内で制御される。

重量平衡判断值：重量変化量が設定値以下であれば、平衡重量と判断さ れる。ここでは水蒸気の場合、120 秒に一度重量を測定し、重量変化量が $10^{-6} \mathrm{~g}$ 以下となった場合、重量平衡と判断される。

重量平衡時間：重量平衡となった後の保持時間。この時間を経過後、重

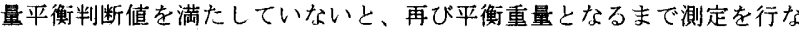
う。

[5] 定電位電解法とは、ガスを特定の電位で電気分解（電解）し、その際に 生じる電解電流を検知してガス濃度を検知するものである。今回使用し た測定器の検出下限值は $10 \mu \mathrm{g} / \mathrm{m}^{3}$ である。

|6] Langmuir 式は式(2)となる。

$$
C_{s}=\frac{C_{s}^{0} K_{L} C^{*}}{1+K_{L} C^{2}}
$$

ここで、( $C_{s}$ 吸着量 $[\mu \mathrm{g} / \mathrm{g}], C^{*}$ s 吸着した分子層濃度 $[\mu \mathrm{g} / \mathrm{g}], K_{L}$ 吸着平衡定数 $\left[1 /\left(\mu \mathrm{g} / \mathrm{m}^{3}\right)\right],\left(:\right.$ 濃度 $\left[\mu \mathrm{g} / \mathrm{m}^{3}\right]$ を表す。

参考文献

[1] B.A.Tichenor, Z.Guo, J.E.Dunn, L.E.Sparks, M.A.Mason : The Interaction of Vapor Phase Organic Compounds with Indoor Sinks, Indoor Air 1, 23-35, 1991

(2) R.B.Jørgensen, O.Bjørseth, B.Malvik : Chamer Testing of Adsroption of Volatile Organic Compounds (VOCs) on Material Surfaces, Indoor Air 9, 2-9, 1999

[3] A.Colombo, M.D.Bortoli, H.Knoppel, E.Pecchio, H.Vissers : Adsorption of Selected Volatile Organic Compounds on a Carpet, a Wall Coating, and a Gypsum Board in a Test Chamber, Indoor Air 3, 276-282, 1993

14] D.Won, R. Corsi, M.Rynes : Sorptive Interactions between VOCs and Indoor
Materials, Indoor Air 11, 246-256, 2001

[5] 安宅勇二, 加瀬田郎, 横山至, 加藤信介, 村上周三：定常法による HCHO 吸収分解せっこうボードの濃度低減効果の検討，日本建築学会大 会学術講演梗概集 D-2,pp875-876,2001

|6| 加藤信介, 村上周三, 朱 清宇, 伊藤一秀 : 揮発性有機化合物の放散·吸 脱着等のモデリングとその数值予測に関する研究（その 26），日本建筑 学会大会学術講演梗概集 D-2,pp809-810, 2001

[7] 鈴木昭人,川合秀治，田辺新一：多孔質セラミックス調湿建材に関する研 究，日本建築学会大会学術講演梗概集 D-2,pp995-996, 2002

[8] 下之園孝, 大河原忠義, 半田晋也, 和久井健洋, 堀 雅宏 : グラフト重合 高分子塗膜剤を用いる室内環境中ホルムアルデヒド低減方法の検討，日 本建築学会大会学術講演梗概集 D-2,pp975-976, 2003

[9] 長谷川麻子, 木村 洋, 小峰裕己, 鎌田元康 : バッシブ型ホルムアルデヒ ド（HCHO）除去製品の简易性能試験方法，日本建築学会計画系論文集， No.548, pp57-62, 2001.10

[10]安宅勇二, 加藤信介, 村上周三, 朱 清宇, 伊藤一秀 : 化学反応型ハヘッシ ブ吸着建材の濃度低減効果に関寸る研究 濃度低減効果測定法の開発と 検証第1 報, 日本建築学会環境系論文集, No.581, pp59-66, 2004.7

[11]安宅勇二, 加藤信介, 朱 清宇, 徐 長厚 : ハッシブ吸着建材のホルムア ルデヒド放散抑制性能試験, 日本建築学会大会学術講演梗概集 D-2, pp1017-1020,2004

[12]桑沢保夫，坊垣和明，大澤元毅，野暗淳夫：吸着性建材の性能測定法に関 するチャンバ実験，日本建築学会大会学術講演梗概集 D-2, pp1021-1024, 2004

[13|安宅勇二, 加藤信介, 朱 清宇, 徐 長厚 : バッシブ吸着建材のホルムア ルデヒド放散抑制性能試験（その3），日本環境管理学会·室内環境学会 合同研究発表会講演予稿集, pp220-223, 2004

[14] A. L. Tiffonnet, P. Blondeau, F. Allard, F. Haghighat : Sorption Isotherms of Acetone on Various Building Materials, Indoor Built. Environ 11, 95-104, 2002

[15] 石丸章: 小容量チャンバーを用いたホルムアルデヒド収着特性試験法，神 奈川県産業技術総合研究所研究報告, No.7,pp79-83,2001

|16| 守屋好文, 宇野克彦, 福田 祐: 有機性ガス等の除去技術について, 空気 調和・衛生工学会学術講演会講演論文集, pp529-532, 2000

[17]安宅勇二, 加藤信介, 朱 清宇, 徐 長厚, 長谷川あゆみ：各種建築材料 および吸着材の吸着等温線の測定, 空気調和・衛生工学会大会学術講演論 文集 D-2,pp1383-1386, 2004

[18| JIS A 1475: 建築材料の平衡含水率測定方法, 2004

[19]近藤精一, 石川達雄, 安部郁夫 : 吸着の科学, 第 2 版, 丸善, 200$]$

[20] ASTM D 6646-01 : Standard Test Method for Determination of the Accelerated Hydrogen Sulfide Breakthrough Capacity of Granular and Pelletized Activated Carbon, 2001

[21]竹内 䔨 監修: 最新吸着技術便覧 - ブロセス・材料·設計-, 初版, エヌ・ ティー・エス, 1999

[22]藤井 実, 吉永 淳, 村瀬陽子, 柳沢幸雄：多孔質七ラミックス建材の室 内空気質浄化機能に関する研究，室内環境学会総会講演集, 92-93, 2001

[23] 竹内 雍, 川井利長, 越智健二, 佐藤忠正: 解説 化学工学, 初版代 11 刷, 培風館, 1988

[24]化学工学協会編 : 化学工学便覧 改訂六版 丸善, 2001

[25]藤原 敏, 嶋 一徹, 千葉意三 : 竹炭の基本的特性と調湿能, 木材学会誌, Vol.49, No.5, 333-341, 2003

[26] 大本道則 他編 : 化学大辞典, 第 1 版, 東京化学同人, 1989

(2005年 1 月 10 日原稿受理， 2005 年 5 月 29 日採用決定） 